\title{
SyMBOLERNAS ARKEOLOGI: TEMAN I EN STUDIE KRING HanNes AlfvÉN
}

\author{
Svante Lindqvist
}

Symboler skapas, manifesteras och försvinner. Fokus för denna uppsats är inte så mycket den medvetna akten att skapa eller att avlägsna en symbol - att så att säga resa en staty eller att välta den frän sin sockel - utan hur artefakter och företeelser långsamt, genom en outtalad kollektiv process, kan förlora sin symboliska betydelse. Ungefär som vimpeln på vår flaggstång framför mitt andra barndomshem.

\section{VeXillologiska MinNEN}

Under sent 1950-tal flyttade vi från en lägenhet i Stockholm till en villa i en förort. Strax efter det att vi hade flyttat dit fälldes flaggstången under stora åthävor. Granstammen skrapades längs hela sin längd från gammal avflagnad färg och linoljemålades på nytt i vitt (detta var före 1960-talets plastfärger). Överst sattes en ny flaggstångsknopp, en gyllene lökkupol. Den köptes i Lidingö Järn- \& Färghandel och var gjord av glas, handblåst förmodligen, och förgylld på insidan med bladguld. (Numera är ju alla flaggstångsknoppar utförda i pressad bleckplåt, och dessa har en betydligt svagare lyster än den skinande kristallkula som pappa packade upp ur silkespappret i kartongen.) Strax under knoppen var ett uttag genom flaggstången där det satt en liten trissa. Genom den fördes flagglinan, och glömde man det innan man reste flaggstången, sade pappa, ja, då hade man problem. När den nymålade flaggstången med sin glänsande topp restes på nytt, fixerades den lodrätt i sitt fundament med stora, genomgående skruvar: En och en halv fot långa och nästan tumstjocka. De imponerade stort på mig, jag hade aldrig förr sett så stora skruvar.

$\mathrm{Nu}$ inköptes en flagga. Den svenska flaggan var viktig, inskärpte pappa. Den skulle behandlas med respekt, man skulle undvika att släpa den i marken och den skulle vikas ihop prydligt ungefär som en bordsduk. Och så detta som gjorde störst intryck på mig: När en flagga blev gammal och utsliten fick man inte slänga den som vilken trasa som helst. Nej, då skulle den eldas upp. Men att flaggor var viktiga det visste jag ju redan. Varje år i början av 1950-talet när vi ännu bodde på Gärdet brukade nämligen mamma ta mig med till "Svenska flaggans dag" den 6 juni på Stadion, ${ }^{1}$ som låg några kvarter längre bort längs Valhallavä- 
28 gen. Där satt hon och jag (pappa var aldrig med, han var alltid på kontoret) och såg, timme efter timme, hur företrädare för den ena korporationen efter den andra marscherade fram och ur Kungens hand fick mottaga en svensk fana. Det var lottaföreningar, hembygdsrörelser, studieförbund, hemvärnsmän m.fl. om vartannat, uppställda i fyrkanter på gräsplanen som vid en truppmönstring. Tre och tre brukade deras företrädare marschera fram och niga eller bocka för Kungen. Personen i mitten av de tre var den som greppade fanan ur Kungens hand, och han höll den sedan mot bröstet som vore den ett fältstandar som han lovat att försvara med sitt liv. Alla dessa föreningsmänniskor, de var alla så oerhört raka i ryggen, tyngda av stundens allvar och alla hade de uniformer av olika slag.

Det bästa var uttåget: Då marscherade alla föreningarna - alla med var sin ny svensk fana i täten för sin tropp - runt hela Stadion på löparbanans kolstybb. Säkert fanns där också en musikkår som spelade, men det minns jag inte (fast den syns på fotot, Fig. 1). Vad jag minns är dock hur jag ställde mig upp och försökte fotografera utgångsmarschen den dag som jag hade fătt min första, egna kamera. Det var en enkel lådkamera med en fast slutartid som gjorde den olämplig för att fånga ting $\mathrm{i}$ rörelse, men den var min stolthet och detta foto från "Svenska flaggans dag" på Stadion 1956 var mitt första fotografi - mitt första egna minne i bild av det förflutna (Fig. 1). Genom att ta detta foto och bevara det deltog jag själv i den kollektiva processen att manifestera och bevara symboler.

Flaggan på vår nymålade flaggstång hissades och halades som den skulle varje söndag under vår första sommar i villan. Jag tycker mig minnas hur pappa står leende vid flaggstången en blåsig och solig sommarmorgon, intrasslad i den väldiga duken och flagglinorna. Eller så är det minnet av något gammal foto som jag nu inbillar mig vara ett synminne, eller kanske är det minnet av en hastigt förbiflimrande sekvens på en $8 \mathrm{~mm}$ film. I början av hösten kom pappa hem med en nyinköpt vimpel. Den var mer än tre meter lång och smalnade av till en pisksnärt. Vimpeln, förklarade pappa, fick till skillnad från flaggan, som skulle hissas kl. 8 på morgonen och halas i solnedgången, hänga uppe för jämnan. (Jag tror att han redan hade börjat tröttna på denna flaggrutin varje söndag, den hade inte längre nyhetens behag.) Vimpeln hissade pappa på vår nymålade flaggstång någon gång $\mathrm{i}$ slutet av 1950-talet, och där fick den hänga. Den smattrade muntert i klara färger, nyinköpt som den var, men efter några år var färgerna blekta av sol och vind. Ja, det var nästan ingen skillnad längre mellan blått och gult. Den var också sliten; uppruggad längs kanterna och den smala spetsen var avnött till en fransad ände på vilken vinden hade slagit några hårda knutar. Hade man sett på den hade den påmint om ett oskarpt, bleknat färgfoto. Men poängen är att man inte länge såg den. Jag lyfte aldrig längre på huvudet när jag kom hem från skolan. Den var inte längre en stolt familjesymbol, utan den hade smält in i den allmänna bakgrund som utgjorde vardagens miljö.

Något år efter det att pappa hade varit i USA för första gången, 1958, började vi regelbundet få besök från Amerika varje sommar. Det var dramatiska höjdpunkter i familjens liv, och på soffbordet av teak låg både Life och National Geographic Magazine. Pappa hade då idén att köpa ännu en flaggstång: Den skulle vara i aluminium och ha en silverfärgad knopp. Den skulle stå bredvid vår vitmålade granstam, och på den skulle den amerikanska flaggan hissas, 


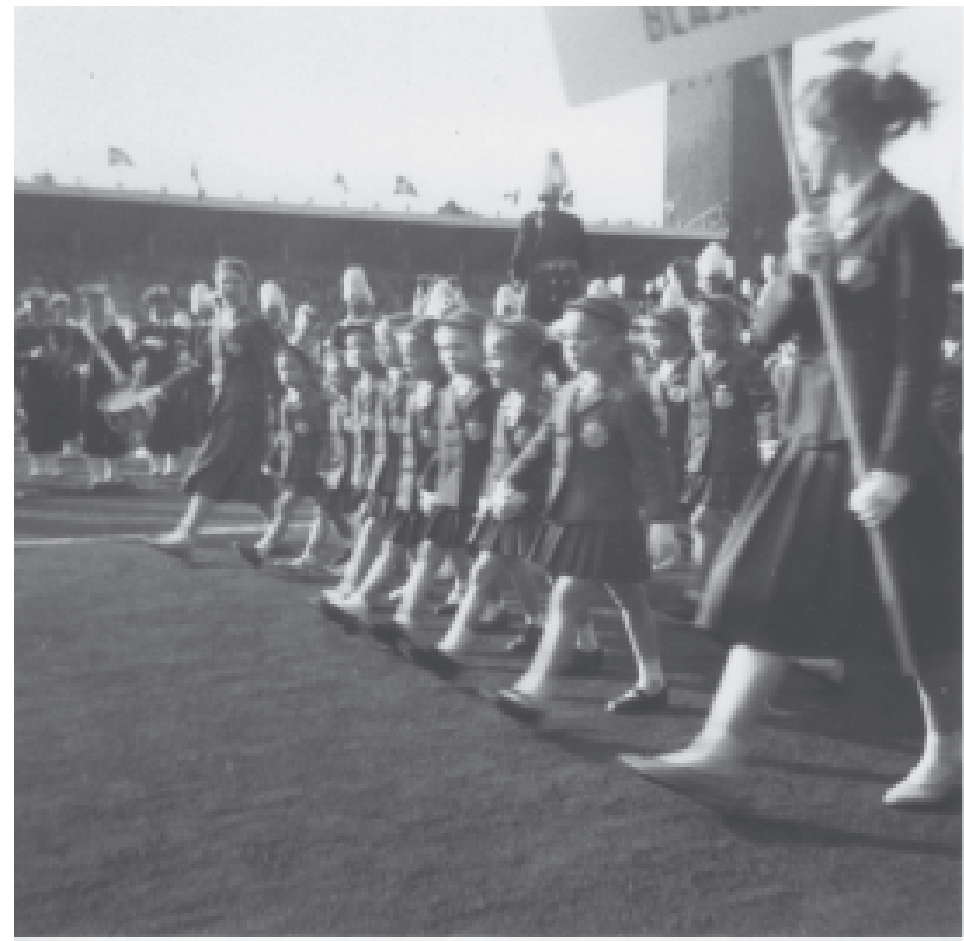

Fig. 1. Defilering vid "Svenska flaggans dag" på Stadion i Stockholm den 6 juni 1956. Foto: författaren 1956.

bredvid den svenska, varje gång vi hade gäster från USA. Jag minns att pappa föreslog det under en frukost, och hur upprörd mamma blev. Det vore att nedvärdera vår Svenska Flagga, menade hon, detta att ha en amerikansk flagga bredvid den svenska på en stång i ett modernare och mer dyrbart material. Pappa suckade lite, och så talades det aldrig mer om den saken.

Och det var vid foten av samma flaggstång som vi stod om kvällarna i slutet av 1950-talet och såg de första satelliterna. Det var en nästan kopernikansk upplevelse: Fixstjärnor som hade lossnat från kristallsfärernas firmament, tecken på att allt var möjligt med vetenskap och teknik. Men satelliterna och sputnikarna var också symboler för den internationella tävlan inom vetenskapen, för "rymdkapplöpningen", ty den rörliga, flimrande ljusprick som pappa pekade ut på den mörka novemberhimlen hade sin självklara nationalitet även om vi inte såg någon flagga.

Ännu ett minne. När jag trettio år senare i slutet av 1980-talet äntligen fick ett eget hus (inte en villa på Lidingö, men väl ett sommarställe utanför Gnesta) så var en av de första saker jag gjorde att ta ner flaggstången. Den stod för en sockersöt nationalromantik från sekelskiftet, för småborgerlighet och kaffekalas i syrenbersån. Det var $\mathrm{i}$ alla fall hur jag 
30 motiverade beslutet inför mig själv, men jag tror nog att bevekelsegrunderna var mer komplicerade än så. Flaggstången föll med ett väldigt brak mot grusplanen (ungefär som när Pariskommunen i maj 1871 välte den väldiga pelaren med Napoleons staty på Place Vendôme). ${ }^{2}$ Den sågades upp till ved, men de stora skruvarna sparade jag i en låda under hyvelbänken. Varför vet jag inte, men jag tar fram dem någon gång varje sommar när jag är ensam i snickarboden; håller dem i handen, vänder och vrider på dem. De imponerar fortfarande (även om det förstås inte är samma skruvar). Vad de minner mig om är inte bara flaggan och USA-besöken i barndomshemmet utan kanske främst den slitna vimpeln - den som jag slutade se därför att den inte längre hade någon symbolisk betydelse.

\section{Symbolernas MÅngFald}

Ovanstående personligt hållna inledning tjänar syftet att fästa uppmärksamheten på ämnet för denna uppsats: Om minnen av det förflutna och om symboler. Mer specifikt handlar den om hur symboler skapas, men också hur de refuseras, förstörs eller bara helt stilla försvinner. ${ }^{3}$ Den museologiska relevansen av detta är uppenbar: De föremål vi bevarar till eftervärlden i tron att de var kraftfulla symboler för sin tid hade kanske sedan länge spelat ut sin roll. Kanske fanns det vid samma tid andra, mindre uppenbara symboler som för sin samtid bar på en större laddning?

Detta intresse för symboler löper som en röd tråd igenom den studie kring Hannes Alfvén och den teknisk-vetenskapliga forskningen i Sverige under efterkrigstiden som jag sedan länge arbetar på. ${ }^{4}$ Låt mig nysta upp några av dessa garnändar för att sedan fördjupa mig i två exempel i syfte att konkretisera frågeställ- ningen. Flera av de blivande kapitlen i Alfvénboken har jag tidigare publicerat som preliminära versioner. I noterna ger jag hänvisningar till dessa uppsatser.

Utgångsmarschen vid "Svenska flaggans dag" på Stadion 1956 har sin motsvarighet i de olika nationella lagens inmarsch på samma Stadion vid invigningen av de olympiska spelen 1912. Jag använder denna bild i (det blivande) kapitel 3 för att illustrera den svenska synen under mellankrigstiden på ett tekniskt museum som en "teknikens olympiad" . 5 Men denna bild kan också symbolisera en generell tendens i pressens rapportering av teknisk-vetenskaplig forskning under efterkrigstiden: Vetenskap som en arena för nationell tävlan. Tidningsrubriker som t.ex. "Norrskenet gav uppslag till svensk världsnyhet", "USA-pris åt svensk tekniker för raffinerat elektronrör" och "Svensk jätteaccelerator överträffas endast i USA" (mina kursiveringar) var legio i pressen under hela efterkrigstiden. ${ }^{6}$ Pressbevakningen av rymdforskningen, "kapplöpningen i rymden", spelade på starka känslor av betydelsen av en internationell tävlan, och i denna Zeitgeist blev även mer blygsamma raketer för jonosfärforskning symboler för modernitet; tecken på att deltaga i den internationella tävlan och ligga långt framme i täten. Sålunda berättade Stockholmstidningen 1960 om dessa små sondraketer att "Sverige först att prova amerikanska rymdraketer", och med jubel kunde Dagens Nyheter utbrista om desamma på sin första sida 1961 "Rymdraketer här". Andra mer subtila symboler för svenska framgångar på den internationella arenan var pressens bilder av svenska delegater på internationella vetenskapliga konferenser, bilder som inte var helt olika de nationella lagens inmarsch på Stadion 1912.

Många av modernitetens symboler under 
efterkrigstiden knöts till just vetenskap och teknik, som t.ex. den 110 m. höga "Atomium" som dominerade världsutställningen i Bryssel 1958. Den blev en ikon för atom- och rymdåldern, åtminstone i Europa. Samma år - 1958 - presenterades det vinnande förslaget till Wenner-Gren Center i Stockholm, vilket hade utförts av arkitekterna Sune Lindström och Alf Bydén. ${ }^{8}$ Byggnadskomplexet blev under sent 1950-tal och 1960-talet en symbol (åtminstone för oss i Sverige) för svensk vetenskap och för dess ställning på den internationella scenen. Ja, på taklagsfesten 1960 jublade Axel Wenner-Gren mot bakgrund av en svensk flagga. Att Wenner-Gren Center i slutet av 1960-talet framstod som en färdig symbol fick sin belysning genom Olle Baertlings respektlösa ifrågasättande 1969 då han helt fräckt föreslog att denna då så symboltyngda byggnad med fördel skulle kunna användas som plint för ett av hans gigantiska skulpturprojekt.

Den närliggande modesta Hagaterminalen, hållplatsen för Arlandabussarna, som invigdes samma år som Wenner-Gren Center, blev något av en symbol för Sveriges närhet till den utländska vetenskapliga scenen. Idag har Hagaterminalen sedan länge mist sin karismatiska ställning, och efter en kort period som lågprishotell för turister sommartid och som natthärbärge för hemlösa vintertid är det numera (år 2003) uppfräschat till ett blygsamt konferenscentrum utan någon som helst symbolisk laddning.

Ett annat, samtida exempel är biografen "Elektron" i Gnesta som också invigdes 1960. ${ }^{9}$ Namnet var en följd av en kommunalpolitisk motsättning: Den borgerliga majoriteten ville undvika att byggnaden kallades "Folkets Hus" och utlyste en pristävling för att finna ett mer neutralt namn. Den sedan några år i Gnesta bosatte Harry Martinson föreslog det vinnande namnet. Martinsons motivering var komplex och gick nog de flesta förbi, men namnet "Elektron" stod 1960 för modernitet och framåtskridande. Neonskylten ovanför entrén (en artefakt som ännu finns kvar) försågs med en stiliserad atommodell som minner om det hundra gånger större "Atomium " vid världsutställningen i Bryssel två år tidigare, 1958. När namnet "Elektron" tillkännagavs fann ortsbefolkningen det förstummande modernt, men idag har det förlorat hela sin symboliska laddning.

Det var inte de vetenskapliga framstegen i sig som fascinerade (dvs. vetenskapen som en världsbildskapande och kulturell verksamhet) utan vad som fängslade intresset var vad dess potentiella tekniska tillämpningar utlovade för framtiden. Den s.k. Rigolettokonferensen, "Tekniken och morgondagens samhälle", som anordnades av det Socialdemokratiska partiet och Landsorganisationen på biograf Rigoletto i Stockholm 1956 gav t.ex. ett löfte för framtiden, "hur tekniken och den grundläggande forskningen kommer att omdana vårt samhälle". ${ }^{10}$ Det främsta syftet med vetenskaplig forskning var (då som kanske också nu) att skapa förutsättningar för att "Sverige även i framtiden liksom tidigare [bör] kunna hävda sig såsom ett av de tekniskt högst utvecklade länderna i världen “. ${ }^{11}$ Det var en stark föreställning som krävde sitt symboliska uttryck på en mångfald olika sätt.

Samma år - 1924 - som Birger Sjöberg skapade sin välkända nidbild av den svenska ingenjören, ingenjör Planertz, grundades den svenska ingenjörskårens främsta symbol, Tekniska Museet. År 1933 sänkte Dragonregementet sin fana på Norra Djurgården för att ge plats åt museets nya byggnad - ett museum som skulle visa på den tekniska utveckling som 
32 hade gjort de beridna soldaterna överspelade. Tekniska Museet, med den svenska flaggan framför huvudbyggnaden som vore den en av rikets befästningar, blev en nationell symbol för svensk teknik och ingenjörskonst. ${ }^{12}$ Dess invigning 1936 var lagd så att den sammanföll med Svenska Teknologföreningens 75-årsjubileum, en mäktig ceremoni med många ideologiska övertoner.

De fanor som vid detta tillfälle kantade museets Maskinhall var de kår- och sektionsfanor som Tekniska Högskolans Studentkår hade antagit vid KTH:s 100-årsjubileum 1917. De är också just dessa fanor som används än idag vid KTH:s årliga promotionshögtider i Stadshuset. (Flera av dem förekommer också varje år under Nobelbanketten i Stadshuset den 10 december när "Students from the Swedish universities and colleges, bearing the standards of their student unions, pay homage to the Laureates". ${ }^{13}$ ) Idag ses $\mathrm{KTH}$ :s fanborg som en harmlös erinran om äldre traditioner, men den kan också ses som en symbol för den föråldrade 1800 tals-struktur inom vilken KTH omvandlades till ett modernt forskningsuniversitet under 1900-talet. ${ }^{14}$ Högskolan expanderade starkt under efterkrigstiden men inom ramen för denna äldre struktur. Kostymen blev för trång, en trådsliten bonjour, men den gamla strukturen fanns kvar - ja, med sektionsnamnen huggna i sten över ingångarna till byggnader som nu användes för andra syften.

I början av 1950-talet anlitades ingen mindre än fotografen K-W Gullers för att skapa en bild av "det nya KTH", den bild av högskolan som man nu önskade framhålla. ${ }^{15}$ Förändringar av hur ordalydelsen i KTH:s symbol, valspråket "Vetenskap och Konst", har tolkats belyser också denna övergång - det var en symbol vars innebörd omtolkades för att passa en ny tid: "Vetenskap" i sin ursprungliga blida 1820-tals betydelse av "systematiserad kunskap" kom att tolkas som mer hårdför "science", och "konst" i sin betydelse av praktisk färdighet kom att tolkas som "estetisk verksamhet”. Mer generellt så kan den flaggstång, den vitmålade granstam, som KTH-teknologerna bar hem från Stockholmsutställningen 1930 till sitt nya kårhus ses som ett uttryck för ingenjörernas kluvna förhållande till modernitet och modernism. ${ }^{16}$

Fascinerande är också hur symboler förstörs eller bara helt stilla försvinner. Ett exempel är "Sverigesalen" på Tekniska Museet, denna storsvenska manifestation av inhemska insatser inom ingenjörskonsten med byster av dess stormän i marmornischer längs väggarna. Den blev otidsenlig på 1970-talet, och salen användes en period som kafé och har sedan dess fătt hysa olika tillfälliga utställningar. Idag står den outnyttjad och marmornischerna gapar tomma.

Ett annat exempel är Jernkontoret, vilket tidigare huserade i en mäktig byggnad vid Kungsträdgården (i hörnet av Kungsträdgårdsgatan och Arsenalsgatan). Det var länge en pampig symbol för den svenska stålindustrins starka ställning i världen, men 1964-65 flyttade man till en mer blygsam byggnad längre ner på Kungsträdgårdsgatan 10. Den ursprungliga byggnaden, med stora medaljonger av svenska naturvetenskapsmän och ingenjörer på fasaden står kvar än idag men byggnaden är nu en del av SE-banken. De dvärgliknande bergsmän med facklor som bevakade entrén står dock kvar på var sin sida om den igensatta huvudporten på Kungsträdgårdsgatan, men de bevakar idag just intet.

På samma sätt stängdes dörren till basutställningen för svensk textilindustri på Tekniska Museet i början av 1960-talet sedan också denna industribransch börjat sin kräftgång på den 
internationella marknaden. Den Svenska Teknologföreningens ståtliga hus på Brunkebergstorg revs under rivningsraseriet $i$ slutet av 1960talet, och därmed försvann också en nationell symbol för den svenska ingenjörskåren - symptomatiskt, eftersom detta sammanföll med den tid då denna kår började förlora sin corps d'esprit. $^{17}$ (Dess nya byggnad är ett anonymt kontorshus på Malmskillnadsgatan.) På ett mindre dramatiskt sätt miste Wenner-Gren Center under slutet av 1980- och början av 1990-talet sin ställning som symbol för svensk vetenskap - dess ideologiska innehåll tynade bara bort helt stilla ungefär som "Sverigesalen" på Tekniska Museet. Idag, när forskningsråd och andra vetenskapliga organisationer sedan länge har flyttat ut ur Wenner-Gren Center och då byggnaden blivit ett normalt affärskomplex, skulle Olle Baertlings förslag inte alls väcka lika starka känslor som det gjorde 1969.

Men i denna historia finns också symboler som refuserades, symboler vilka aldrig fick fylla sin tilltänkta roll, som t.ex. Otto G. Carlsunds förslag till väggmålningen "Ingenjörskonstens sju skolor" i KTH:s kårhus - ett förslag som teknologerna enligt ryktet mottog gapskrattande och rev sönder i småbitar. En kraftfull symbol för den kritiska syn på tekniksamhällets framtid som Hannes Alfvén representerade hade kanske Karl-Birger Blomdahls uppsättning av Alfvéns science-fiction berättelse Sagan om den stora datamaskinen blivit om inte tonsättaren helt plötsligt avlidit 1968 mitt under arbetet. ${ }^{18} \mathrm{Ja}$, kanske hade den blivit en ny "Aniara".

Alla dessa flaggor och andra handgripliga symboler som t.ex. byggnader har en självklar påtaglighet, men det fanns också många nationella föreställningar om vetenskap och om Sveriges roll på den internationella scenen vil- ka inte lika lätt lät sig visualiseras men som ändå fann sin symboliska form. Ett exempel är den allmänna oron för "forskarflykt", skräcken för en nationell åderlåtning, att förlora begåvningar och därmed halka efter i den internationella konkurrensen. En person som Alfvén (vilken sedan 1967 tillbringade varje vinterhalvår vid University of California-San Diego i La Jolla) och hans begåvade elev Bo Lehnert (som ständigt hotade med att acceptera nya smickrande erbjudanden från amerikanska prestigeuniversitet) blev symboler i pressen för denna nationella fruktan.

En annat exempel var Hannes Alfvéns nya elektronrör, trokotronen, vilket ofta framhölls i pressen. Trokotronen blev - om än aldrig någon teknisk framgång - emblematisk för tron på den linjära modellen (dvs. att det råder ett enkelriktat kausalsamband mellan vetenskaplig grundforskning och teknisk utveckling), och den fick därmed tjäna som en symbol för det nya KTH. ${ }^{19}$ På samma sätt blev Hannes Alfvéns korta artikel i Nature 1942 om magneto-hydrodynamiska vågor - den, vilken sades ha givit honom Nobelpriset - en ikon vilken reproducerades som bild snarare än som text; en symbol för individuell (svensk) genialitet.

Dagspressen hjälpte till att skapa många av dessa symboler för svensk vetenskap genom att konstruera bilder av förutfattade kollektiva uppfattningar om hur det förhöll sig (eller borde förhålla sig). Det finns en uppsjö av sådana arrangerade bilder i efterkrigstidens presslägg av vetenskapsmän bredvid sina apparater, tillsagda av fotografen att låtsas "inspektera", "diskutera" eller "dryfta" dem. Ett exempel är när Hannes Alfvén i La Jolla var tillsagd av Dagens Nyheters fotograf att spela rollen av hur man här hemma föreställde sig bilden av "en svensk professor i Kalifornien"; dvs. sittande 
34 bland solande studenter i gröngräset iförd kostym och svensk tjänstemannaportfölj, eller vadande vid strandkanten av Stilla Havet med uppkavlade kostymbyxor och vita vador. Vid detta tillfälle - just när Nobelpriset 1970 tillkännagivits - hade Dagens Nyheter större tur med sina bilder än Svenska Dagbladet eftersom tidningen råkade ha en fotograf i landet när priset tillkännagavs. Svenska Dagbladet fick nöja sig med en suddig, telefaxad bild av Hannes Alfvén i telefonen; en bild som skulle implicera det osannolika att den hade tagits det ögonblick han fick telefonsamtalet från Stockholm kl. 04.00.

Andra exempel på arrangerade pressbilder finns i historien om Wenner-Gren Center. Pressen sökte skapa en bild av en verklighet som ej existerade, de sökte bekräfta sina egna förutfattade meningar och läsekretsens förväntade föreställningar om hur världen såg ut. Det var en värld där isprinsessan gick ned på knä en kylig Luciamorgon på den igenfrusna dammen vid Wenner-Gren Center för att "samtala" med ett amerikanskt och två sudanesiska forskarbarn, vilka skenbart händelsevis råkade sitta bredvid varandra (sannolikt hopfösta av fotografen för maximal exotism). Eller där styrelsen för Stiftelsen Wenner-Gren Center radades upp på ett led, alla vända åt samma håll (dvs. åt fotografens), och i bildtexten påstods att kameran fångat dem när de höll på att "diskutera det vinnande förslaget" - en osannolik händelse under en pågående presskonferens och dessutom inte särskilt bekvämt.

Hannes Alfvén blev själv en symbol för svensk vetenskap och för förhoppningarna om vad denna vetenskaps tekniska tillämpningar inom bl.a. elektronik och fusionsforskning skulle komma att betyda i framtiden för Sveriges välstånd och landets internationella anseende. Att studera hur bilden av Alfvén for- mades och förändrades är därför detsamma som att studera synen på svensk vetenskap och teknik under efterkrigstiden. Genom ett stort antal artiklar och notiser om Alfvén i svensk press under flera decennier skapades en bild, en föreställning om honom och hans verksamhet. Denna bild kan analyseras rent konkret i termer av just de olika porträttfoton av honom som pressen valde som illustrationer till dessa artiklar. ${ }^{20}$ Från slutet av 1960-talet finns det i princip två typer av konkurrerande bilder (representerade av 3-4 porträttfotografier vardera) av Alfvén i svensk press: Miljökämpen-Kärnkraftsmotstådaren vs. AkademikernNobelpristagaren. Denna motsättning i bildval, dessa bilder som kämpar mot varandra för utrymme, avspeglar en polarisering av tekniksamhället och synen på dess framtid - och det var en polarisering och förenkling som Alfvén själv i hög grad bidrog till att åstadkomma. Även i dessa teknikpolitiska sammanhang förekommer flaggor: Vid den mäktiga demonstrationen 1976 mot uranskifferbrytningen i Ranstad, den s.k. "Västgötabergens dag”, där Hannes Alfvén var huvudtalare, användes svenska flaggor för att spela på nationella känslor av ödesmättad betydelse.

Men också Hannes Alfvén själv - eller snarare den mediala bilden av honom - blev en symbol för samtidens förhoppningar. Hans uppfinning trokotronen tycktes bekräfta föreställningen att vetenskaplig grundforskning skulle leda till teknisk utveckling och ekonomisk tillväxt och därmed stärka Sveriges ställning internationellt. Hans teori om universums ursprung, hans starka tro på att fusionskraften skulle lösa världens energiproblem, hans skröna om den stora datamaskinen - ja, allt detta gav resonans i det samtida Sverige med dess förhoppningar om att grundforskning skulle ge Sverige dess rättmätiga ställning 
i det internationella samfundet. Sin officiella sanktion som symbol för dessa förhoppningar fick bilden av Alfvén när han 1970 tilldelas Nobelpriset i fysik. Därmed kopplades Alfvén till den kanske största och ännu ej sorgfälligt granskade symbolen för svensk teknik och vetenskap under 1900-talet: Nobelpriset, och den därmed associerade bilden av Alfred Nobel. ${ }^{21}$ Desto mer komplicerat och laddat blev det därför när han under 1970-talet valde att ta ställning mot kärnkraften. ${ }^{22}$

\section{“De ELEKTRISKA STRÖMMARNA"}

För ett exempel på hur symboler bara helt stilla kan försvinna beger vi oss till Kungl. Tekniska Högskolans mäktiga huvudbyggnad, ritad av Erik Lallerstedt och färdig 1917. Den är anmärkningsvärt rik på konstnärlig utsmyckning, ${ }^{23}$ och flera av dessa konstverk tillkom genom donationer från svensk industri. Även en tillfällig besökare kan inte låta bli att observera flera verk av Carl Milles, bl.a. den stora reliefen i bränt glaserat lergods över huvudentrén ("Människans strid med elementen”). Därtill kommer kalkmålningar av Hilding Linnqvist och Georg Pauli, ett stort antal reliefer av Ivar Johnson, takfältsmålningar av Olle Hjortzberg m.m. Det är dock inte dessa arbeten som vi skall diskutera här utan en takmålning av Axel Törneman (1880-1925). ${ }^{24}$

Törneman hade studerat vid Valand i Göteborg samt i München, Dachau och Paris. Hans mest kända verk från Paristiden är "Nattcafé II“ (1906), vilket vi strax skall återkomma till. Återkommen till Sverige gjorde han muralmålningar bland annat i Värmlandsbanken, Östra Real och - efter många kontroverser - i andra kammarens plenisal. ${ }^{25}$ När han dog 1925, bara fyrtiofem år gammal i blödande magsår, skrev John Landqvist i en minnes- runa i Aftonbladet att bland Törnemans "mest fulländade verk äro hans takmålningar i en sal i nya Tekniska Högskolan”. ${ }^{26}$ År 1916 hade Törneman fătt i uppdrag av Lallerstedt att utsmycka Fackskolan för elektroteknik, och under 1917 utförde han skisser till en takmålning i dess stora hörsal. Arbetet kunde inte påbörjas förrän några veckor efter det att de nya byggnaderna hade invigts 1917 , och först sedan Lallerstedt hade säkrat en donation på 10.000 kronor från ASEA. Det hade krävt ett intyg till ASEA:s styrelse i Västerås - undertecknat av bland andra Richard Berg, Christian Eriksson, Olle Hjortzberg och Carl Laurin - att målningen skulle bli av högsta konstnärliga värde och "en synnerligen önskvärd och för Högskolan ståtlig prydnad". ${ }^{27}$

I ett brev till sin far 1917 berättade Törneman att han hade "för dyra pengar inköpt ett stort arbete öfver Elektriciteten för att upplifva mina kunskaper om naturkraften ifråga" ${ }^{28}$ Törnemans skisser, bevarade vid Arkivet för dekorativ konst i Lund, visar att han snart fastnade för en allegorisk framställning av vad han kallade "de elektriska strömmarna"; manliga och kvinnliga väsen, svävande i motsatta riktningar i var sin ring runt en gyllene sol. ${ }^{29}$ Målningen utfördes al secco, på den torra putsen, av Törneman själv. Från ställningar överförde han först sina skisser i kol till taket med hjälp av en stans. Pressvisningen 1918 gav genomgående goda recensioner i Dagens Nybeter, Stockholms- Tidningen och Stockholms Dagblad. Recensenten i Svenska Dagbladet raljerade dock och tyckte att de "kraftiga solbrynta manskropparna" mest föreföll som elektriska arbetare, och att kvinnogrupperna var "utomordentligt välgödda” ${ }^{30}$ En senare recension framhöll "rytmiken i grupperna, den vackra växlingen av vila och rörlighet, av passivt hängivande och aktiv strävan” ${ }^{31}$ 
Svante Lindevist

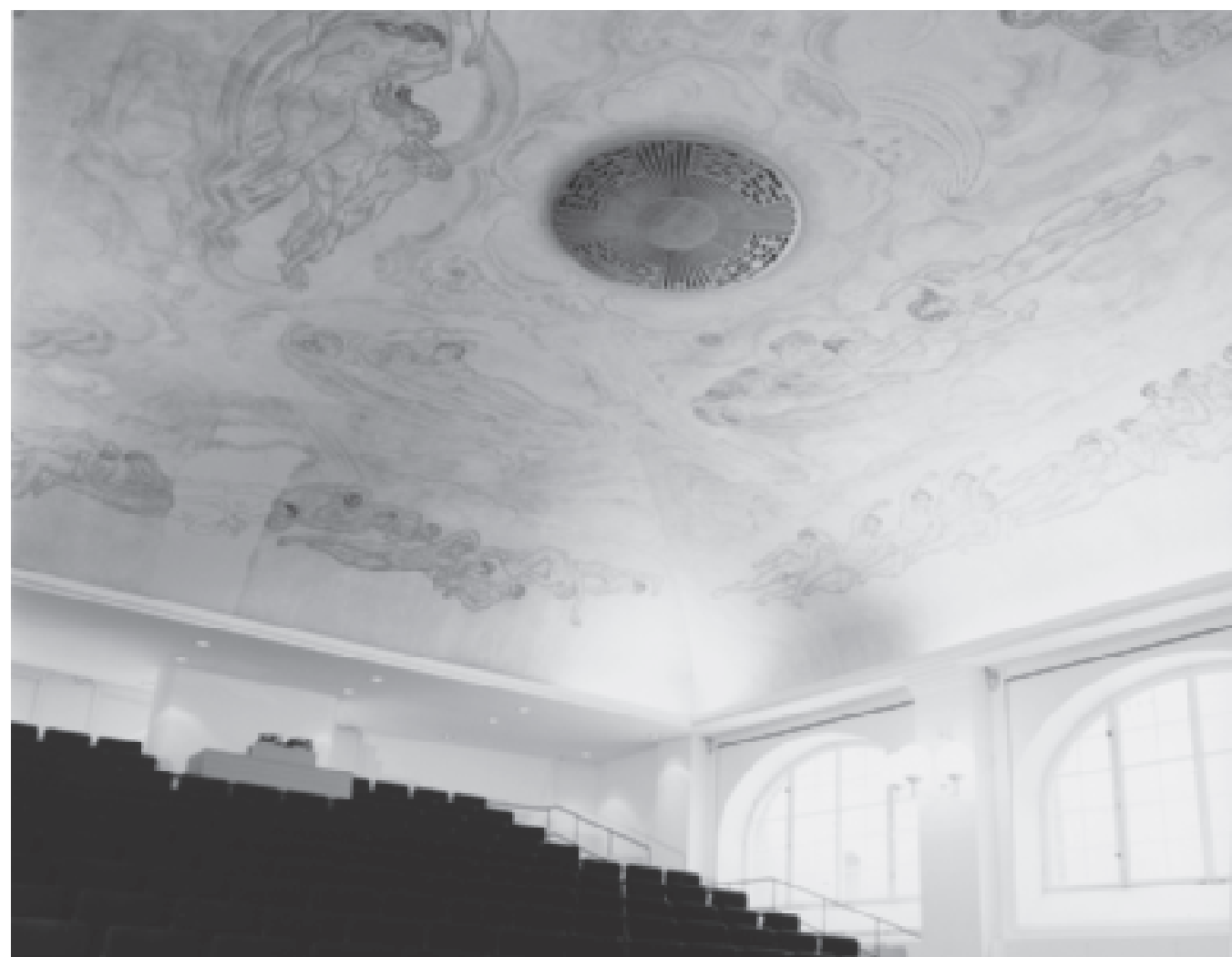

Fig. 2. Vy av Axel Törnemans takmålning "De elektriska strömmarna" sedan den 1993-1994 hade flyttats till en nyrenoverad lärosal på Kungl. Tekniska Högskolan. I fonden syns konturerna av den del som förstördes när en dörr togs upp genom takmålningen under 1950-talet i den lärosal där den hade utförts 1917. Foto: Tomas Asplund 1997.

Under 1950-talet - det är ännu oklart exakt när - "försvann" målningen. Den officiella förklaringen är att högskolans behov av lärosalar hade förändrats, och att hörsalen i den elektrotekniska fackskolan nu var för stor för en årskurs men för liten som aula för hela högskolan. ${ }^{32}$ Då hörsalen löpte genom två våningar vann man $700 \mathrm{~m}^{2}$ i kontorsutrymmen genom att lägga in två nya bjälklag. Målningen blev dold högst upp i ett kupolutrymme som användes för att dra ventilationskanaler till de nya rummen. Att den fanns kvar någonstans på högskolan visste man, men redan på 1970talet var det ingen längre som visste var. $^{33}$

I samband med restaureringen av huvudbyggnaderna på 1990-talet återupptäcktes dock målningen år 1993. Man bestämde att flytta den $216 \mathrm{~m}^{2}$ stora målningen till en annan, nyrenoverad lärosal vars form och storlek var snarlik den ursprungliga hörsalen. 


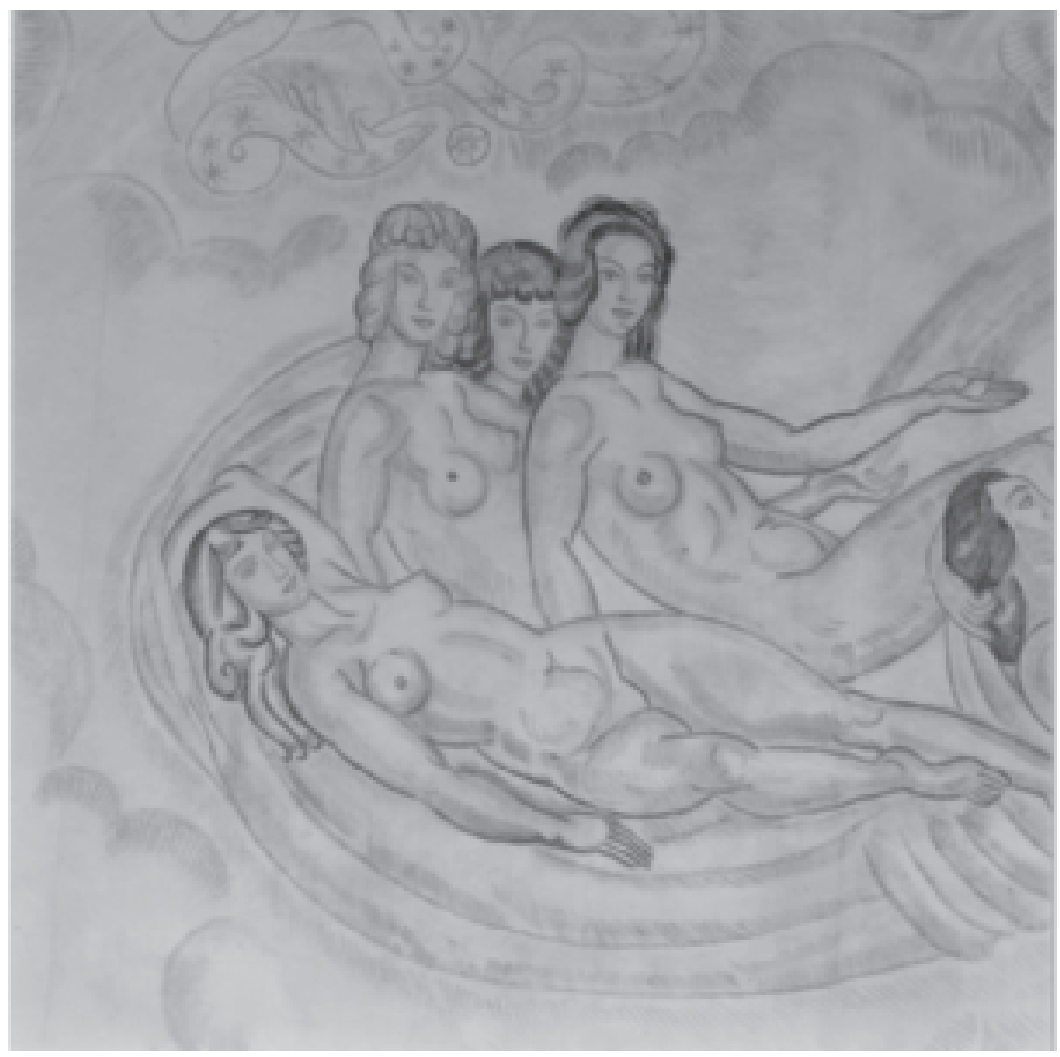

Fig. 3. Detalj av Axel Törnemans takmålning "De elektriska strömmarna". Foto: Tomas Asplund 1997.

Målningen flyttades med den italienska s.k. strappometoden vilken bara avlägsnade de 0,5 $\mathrm{mm}$ tjocka färgskikten (grundfärgen och figurfärgerna) och därefter limmades skikten upp på den nya platsen. Arbetet tog ett år, och 1994 återinvigdes målningen.

Det som fascinerar här är dock inte målningens tillkomsthistoria under 1910-talet, och inte heller den dramatiska återupptäckten och dess flyttning på 1990-talet. Nej, vår uppmärksamhet är riktad mot någonting betydligt vagare och mer svårfångat under mellantiden. Nämligen detta: Varför tilläts den falla i glömska? Varför dolde man målningen bakom ett innertak, och tog helt brutalt upp en dörr rakt igenom den? Det här väcker ett mer allmänt spörsmål: Vad är det för mekanismer som gör att offentlig utsmyckning en av sin samtid högt värderad konst - efter ett antal år mister sin betydelse och förvandlas 
38 från konst till något som tillåts förvittra, förslitas och slutligen i tysthet försvinna? Historiskt sett är ju detta ett öde som har drabbat den allt överskuggande delen av den offentliga konstnärliga utsmyckningen i världen. Det är ju bara en bråkdel som har bevarats som byggnadsminnesmärken eller i museer. Hit hör i det långa perspektivet till exempel Ninives palats eller antikens tempel. Deras försvinnande tillskriver vi gärna krig och andra katastrofer, men säkert är att många av dem tilläts förfalla långt innan de förstördes. Att de med tiden övergavs och lämnades att vittra sönder.

I ett kortare och mindre pompöst perspektiv gäller det ju också våra egna städer, större byggnader och deras offentliga utsmyckning. Sålunda är till exempel listan lång på skulpturer i Stockholm som först givits en central placering i stadsbilden, vilka har avtäckts med högstämda hyllningstal, musik och fanborg bara för att några decennier senare $\mathrm{i}$ tysthet flyttas till en mer avlägsen plats, eller som helt sonika har avlägsnats och försvunnit. ${ }^{34}$ Det finns en skriande diskrepans mellan den högljudda offentlighet med vilken konstnärlig utsmyckning invigs och den tysta fördoldhet i vilken den tillåts försvinna. I det ena fallet högtidsklädda människor med allvarliga anletsdrag och stor värdighet, följande ett elaborerat ceremoniel, en strikt hierarki. I det andra ett beslut av en lägre, ointresserad tjänsteman på sitt kontor, verkställt utan åthävor av en verkmästare och några arbetare med skovlar och en gaffeltruck en glåmig vardagsmorgon. Vi har alla bilder på näthinnan av hur statyer av Lenin och Saddam Hussein välts från sina socklar under senare år, men - bildligt talat - sannolikt är de inramade foton av Hitler, vilka $\mathrm{i}$ all tysthet, utan ceremoniel och i ensamhet, flyttades bort från flygeln och spiselkransen 1945 betydligt fler.
I det här fallet gäller det dock varken Ninives palats eller Tredje Riket utan något så trivialt som den konstnärliga utsmyckningen i en lärosal i en nordeuropeisk teknisk högskola. Problematiken är dock generell och värd att uppmärksamma - denna tysta och fördolda ikonoklasm. Varför tilläts Törnemans målning att försvinna? Bortglömd av den konstnärliga expertisen var den aldrig, men den ansågs förkommen. Poängen är att den förlorade sin roll som offentlig konst någon gång på 1950 -talet. Om vi kan bestämma vilka värderingar den stod för vid sin tillkomst så säger dess tysta försvinnande oss att samtiden inte längre delade dessa värderingar. Att studera hur offentlig konst försvinner blir därmed också ett sätt att studera värderingars förändringar.

Vad det gäller Törnemans symbolik - dikotomin mellan manligt och kvinnligt för positiv och negativ elektricitet - kan det hävdas att den har sina rötter i den romantiska naturfilosofin. Bo Sundin har påpekat att upptäckten av elektromagnetismen är ett intressant exempel på hur avgörande naturvetenskapliga framsteg kan stå i samband med sin tids filosofi och kulturliv. ${ }^{35}$ Ørsteds berömda skrift 1820 om upptäckten av elektromagnetismen hade titeln Försök över den elektriska konfliktens verkan på kompassnålen-och som en konflikt såg Ørsted och andra romantiska naturfilosofer tillvaron, som formad av motsättningar mellan olika krafter där den materiella världen bara var ett yttre fenomen.

Den romantiska naturfilosofin gick tillbaka på Kants dynamiska naturuppfattning med dess två grundkrafter: Den attraherande och den repulsiva. Schelling och andra romantiska naturfilosofer utvecklade Kants dynamism till en världsbild där tillvaron beskrevs som ett gigantiskt kraftspel i vilken en central princip var naturens polaritet - den överallt existeran- 
de dualismen mellan motsatta krafter: "På område efter område spårades denna princip. Elektriciteten har således två poler. Så även magneten. Gravitationskraften balanseras av en centrifugalkraft. [...] Mot liv står död [...] ljuset står mot mörkret, vintern mot sommaren, varmt mot kallt, krig mot fred, kärlek mot hat", ${ }^{36}$ och så - liksom i Törnemans målning - kvinna mot man.

Men lika viktig i den romantiska naturfilosofin som polaritetstanken var enhetstanken. Att det bakom detta kraftspel fanns en grundläggande enhet, en enhetskraft: Den skapande anden som var av gudomlig natur. Även denna har sin givna plats i Törnemans takmålning; nämligen i den stiliserade sol i takets mitt kring vilken figurerna svävar. (Solskivan är ett galler som döljer en ventilationstrumma - en kanske väl prosaisk funktion för Det Högsta Väsendet, den evigt skapande anden i naturen. ${ }^{37}$ ) Att se en återklang av den kantianska dynamismen i takmålningen i hörsalen till den Elektrotekniska fackskolan på KTH är dock en hårdragen tolkning. Snarare ärTörnemans symbolik att betrakta som ett tecken på den populärvetenskapliga föreställningsvärlden i seklets början i vilken en efterklang av den romantiska naturfilosofin hade dröjt sig kvar.

Vi kan också i Törnemans målning se ett tidstypiskt uttryck för ett nytt kvinnoideal, etablerat i början av 1900-talet, något som Karin Johannisson beskriver i sin bok Den mörka kontinenten: Kvinnan, medicinen och finde-siècle. ${ }^{38}$ Den sjukliga kvinnan som borgerlig idealtyp tynar bort efter sekelskiftet, skriver hon. Sekelskiftets växande oro för ett vikande befolkningsunderlag kopplades till tankar om en degeneration av samtidsmänniskan, "allt mindre duglig att alstra ett fullgott befolkningsunderlag". ${ }^{39}$ Med befolkningspoliti- ken som norm präglades en ny kvinnobild. "Den starka kvinnan behövdes: inte förfinat blek och skör, utan frisk och alstringsduglig." 40 Det är lätt att i kvinnofigurerna i Törnemans takmålning från 1918 se ett uttryck för detta nya kvinnoideal: Kraft, vitalitet och sundhet.

Symboliken i Törnemans målning - dvs. den okomplicerade och rättframma dikotomin mellan motsatser - framträder desto klarare om vi kontrasterar Törnemans takmålning mot en annan av hans tidigare målningar, hans genombrottsarbete "Nattcafé II" från 1906. ${ }^{41}$ Det är en målning som, skriver Ulf Linde, ”genom sin dekadens och fräna färg väckte sensation när den först visades i Sverige". ${ }^{42}$ (Ernest Thiel köpte genast målningen, och den hänger idag på Thielska Galleriet.) Det är inte bara den fräna färgen som skiljer "Nattcafé II" från "De elektriska strömmarna", utan framförallt förhållandet mellan män och kvinnor. Axel Törnemans kvinnosyn var komplicerad: "Han svingar sig från måttlös idealisering till den bittraste cynism” skriver Pontus Hultén, och Ulf Linde talar om "hans besatthet av kvinnan". ${ }^{43}$

Scenen är ett av sekelskiftets kontinentala nattcaféer, troligtvis i Paris (målningen tillkom under Törnemans Parisvistelse 1902-1906). Bilden domineras av två kvinnor vid ett bord - och att två kvinnor utan manlig eskort på offentlig lokal var detsamma som två prostituerade var ju chockerande uppenbart för Törnemans samtid. Som seden var på kontinentens nattcaféer har de två på vinst och förlust beställt in en flaska champagne (som står mellan dem i en ishink på bordet). Den dricker de långsamt, skenbart konverserande, under det att de i ögonvrån bevakar de manliga gästerna. Förhoppningen var ju att någon herre, på väg hem från operan eller en middag, skulle komma in på nattcaféet för en drink på jakt 
40 efter kvinnligt sällskap. Föll han för någon av dem, i konkurrens med deras medsystrar vilka väntade på samma sätt vid andra bord, betalade han deras nota och den utvalda följde med honom.

Kvinnan i mitten, den äldre av de två, är mager, hård och sliten under sminket. Hennes spända nacke signalerar hennes nervositet - betraktaren anar att hon nu nått en punkt i livet då hon bara alltför ofta ej förmår attrahera någon lebeman i konkurrensen utan själv får betala champagnen när caféet stänger framåt morgonen. Hennes yngre kompanjon, som med ryggen mot betraktaren konverserar sin spända väninna, har hängt av sig kappan på stolen och satt upp armen på bordet för att exponera sig mot mannen längst till vänster. Hans kroppsspråk företer alla tecken på en utfestad vivör, det sista stadiet av en lyckad kväll för en rucklare. Med huvudet på sned vilar han tungt mot armbågen på bordet. En cigarett dinglar i hans slappa, aristokratiskt smala hand, vilken avtecknar sig i skugga mot det stärkta skjortbröstet. Hon söker attrahera honom, men om han överhuvudtaget har noterat henne är oklart. Det hela är honom likgiltigt ty hans attraktionskraft är given i kraft av hans ekonomiska överläge, och han bestämmer själv om han vill utnyttja den.

Det är således inte en bild som går att uttrycka i romantikens naturfilosofi, dvs. som ett kraftspel med en ömsesidig attraktion mellan likvärdiga laddningar. Från kvinnornas sida är attraktionen bara ett nervöst spel, från mannens sida ett lojt överläge. Mannen och kvinnorna på tavlan "Nattcafé II" står således i starkt kontrast till de sunda och hurtfriska ungdomar som valsar runt i taket på hörsalen till den Elektrotekniska fackskolan. Den konstnärligt uttryckta spänningen mellan man och kvinna i det senare fallet är dels rent biologisk (kvinnor och män), dels kompositionell - dvs. i olika grupper och i rörelse åt olika håll. Den erotiska spänningen ges ingen konstnärlig gestaltning utan får antagas à priori på grundval av det faktum att dessa välgymnastiserade atleter alla är ungdomar i fertil ålder. Det vilar något av en trist, sund moralism över "De elektriska strömmarna" i jämförelse med "Nattcafé II".

På 1950-talet, när man i tysthet lät Törnemans takmålning på KTH försvinna utan att någon ifrågasatte eller ens brydde sig om det, var dess vetenskapliga symbolik sedan länge överspelad, och den bör ha tett sig skäligen enkel för 1950-talets teknologer. Dikotomin mellan positiva och negativa laddningar, med sina rötter i romantikens naturfilosofi, var för dem en trivialitet, och som en illustration av den elektriska strömmen var allegorin tveksam eller direkt felaktig. Pluralformen ("de elektriska strömmarna") är förvirrande emedan en elektrisk ström nu som då definieras som en rörelse av laddningar från positiv till negativ potential. På målningen sker dock ingen rörelse mellan de två, från positiv till negativ potential, utan män och kvinnor driver runt $\mathrm{i}$ var sin cirkel. Ett magnetfält, vinkelrätt mot takets plan, skulle visserligen driva positiva och negativa laddningar i cirkelformade banor med motsatt riktning - något som minner om cyklotronen, en uppfinning från 1930-talet ... Ja, så kunde en teknolog ha funderat på 1950talet, hade han lyft huvudet mot taket. ${ }^{44} \mathrm{Mer}$ spännande var då den nya fysik som hade utvecklats och slagit igenom sedan Törneman utfört sin takmålning, till exempel kvantmekanikens våg-partikeldualism och obestämdhetsrelation. Positiva och negativa laddningar sågs under efterkrigstiden inte som distinkta biljardbollar, bestämda till form och läge, utan som betydligt mer obestämda sannolikhetsför- 
delningar med vågnatur. Under alla förhållanden så lät sig inte den nya fysikens materieuppfattning illustreras av naturalistiskt utförda människokroppar, exakt bestämda till form och läge av sina konturer.

Törnemans målning associerade således till den klassiska fysiken och därmed till 1800-talet. Därmed associerade den också till den tid då KTH hade varit en polyteknisk läroanstalt av 1800-talssnitt, en utbildningsanstalt utan universitetsstatus. För den högskola, som sedan 1927 ägde rätt att promovera teknologie doktorer, och som under efterkrigstiden hade påbörjat sin omvandling mot ett modernt forskningsuniversitet var detta en ovälkommen association. Törnemans gestaltning av synen på naturkrafterna var hämtad från en tid som man önskade distansera sig från. Säkerligen var detta inte något medvetet beslut, ingen uttalad föreställning. Bildspråket var bara helt enkelt främmande för 1950-talets tekniker. Det sade dem intet. Det var bara en "gammal" målning, och detta sagt eller tänkt i en kulturell miljö - ingenjörskulturen - där "gammal" står för åldrig snarare än för antik, för värdelös snarare än för värd att bevara. Det var en kvalitet som vägde lätt mot möjligheten att skaffa sig $700 \mathrm{~m}^{2}$ extra kontorsutrymme.

På 1950-talet pågick också som bäst KTH:s stora byggnadsexpansion. Högskolan fick förtroendet att bygga i egen regi, och nu uppfördes ett stort antal nya laboratorier och lärosalar. Det röda teglet var snarlikt det i byggnaderna på 1910-talet, men formspråket var den moderna arkitekturens. Högskolans äldre byggnader sågs nu som en belastning snarare än som en tillgång. Det var i den processen som Törnemans takmålning förvisades till "de refuserades salong". Nu var den bara en gammal målning av ringa intresse som självklart fick stryka på foten inför den stora expansio- nen, särskilt som den gav associationer till en tid som man önskade distansera sig från.

Sedan dess har pendeln svängt på nytt. Under 1990-talet har de äldre byggnaderna renoverats och framhålls nu med stolthet. I den pendelrörelsen sveptes så att säga Törnemans takmålning med - den återupptäcktes och renoverades till ett kostnad som säkert skulle ha fått konstnären själv att dåna. (Att flytta takmålningen kostade ca 5 gånger så mycket som kostnaden för det ursprungliga utförandet. ${ }^{45}$ ) $\mathrm{Nu}$ hade den så att säga förvandlats från en "halvgammal" målning" till en "helgammal" dito och kunde utnyttjas för att understryka anciennitet och tradition. Det hade nu gått så lång tid sedan dess tillkomst att den var helt fri från äldre tiders värderingar - dess bildspråk var inte längre vårt eget. Den säger oss just ingenting, och vi intresserar oss egentligen inte heller för vad det sade människor vid seklets början. Nu är det dags för en ny tid att fylla form och bild med ett nytt idéinnehåll.

\section{"Framtiden, Nutiden, FörfluteT"}

För ett exempel på den kollektiva process i vilken symboler skapas beger vi oss på nytt till KTH. Skulpturgruppen "Framtiden, Nutiden, Förflutet" framför den nya Elektroteknikbyggnaden vid KTH på Osquldas väg 4 utfördes år 1990 av konstnär Ebba Ahlmark-Hughes (Fig. 4). ${ }^{46}$ Dess tillkomst exemplifierar hur symboler skapas i det vaga samspelet mellan konstnär och beställare. Andra exempel på detta som har nämnts här tidigare är Sune Lindströms och Alf Bydéns arkitektoniska gestaltning av idén bakom Wenner-Gren Center, samt K-W Gullers fotografiska gestaltning av KTH som ett modernt forskningsuniversitet. I samtliga fall är processen likartad: Konst- 
42 närens egna förutfattade meningar och föreställningar om vad uppdragsgivaren önskar symbolisera modifieras i en nära dialog mellan konstnär och beställare.

Hur tillkommer en offentlig konstnärlig utsmyckning som skulpturgruppen "Framtiden, Nutiden, Förflutet"? Ansvaret för att det blev en konstnärlig utsmyckning vid den nya Elektroteknikbyggnaden vilade på Statens konstråd, och KTH hade under dåvarande Kungl. Byggnadsstyrelsens egid en referensgrupp för konstnärlig utsmyckning av den nya Elektroteknikbyggnaden bestående av lärare och tjänstemän. ${ }^{47}$ Valet att inbjuda Ebba Ahlmark-Hughes skedde efter visning av diabilder på Statens konstråds kansli för KTH:s referensgrupp och husets arkitekter. ${ }^{48}$ (Statens konstråd hade en stor samling med verk av olika svenska konstnärer.) Konstrådets handläggare föreslog referensgruppen namnen på några skulptörer som skulle kunna utsmycka platsen, och referensgruppen "var enig om att av de föreslagna skulptörernas arbeten 'tyckte vi bäst om' Ebba A-Hs verk" . ${ }^{49}$ Ebba AhlmarkHughes fick därefter en inbjudan från Statens konstråd att lämna förslag till "berikande av uteplats-entré-restaurang i anslutning till projekt KTH, sekt E, Kungliga Tekniska Högskolan, Elektroteknik, Nybyggnad". ${ }^{50}$ Efter några månader fick KTH:s referensgrupp se på skisser och gipsmodeller och träffa AhlmarkHughes som "beskrev sina tankar mycket engagerat". ${ }^{51}$ Innan KTH:s referensgrupp fick se förslaget hade det dock redan behandlats i Statens konstråds styrelse som hade godtagit förslaget, och KTH:s referensgrupp tyckte att det "var ju lite underligt att referensgruppen pro forma fick 'godta' förslaget när det redan hade tillstyrkts av Konstrådet”. ${ }^{52}$ Ahlmark-Hughes har berättat att "När så småningom skissförslaget presenterades och godkänts, följde in- tressanta samtal mellan arkitekt, trädgårdsarkitekt och mig själv". ${ }^{53}$ Här avhandlades en mängd praktiska ting, ty det "gällde att få den slutliga placeringen av skulpturgruppen att stämma med höjdförhållanden, grönska, avrinning, [...] hänsyn till skyltar, cykelställ och sittgrupper utomhus". ${ }^{54}$ Sedan KTH:s referensgrupp hade fătt tillfälle att ta del av och (om än pro forma) tillstyrka förslaget till konstnärlig utsmyckning av nybyggnad 50:16 skrev KTH till Byggnadsstyrelsen:

Rektorsämbetet får härmed med tillstyrkan överlämna referensgruppens yttrande och anhålla om att byggnadsstyrelsen medverkar till att föreslagna konstverk kommer till utförande. ${ }^{55}$

Byggnadsstyrelsen skrev därefter till Statens konstråd:

KBS-BP:s handläggare för rubr projekt har 1989-0110 tagit del av konstnärinnan Ebba Ahlmarks förslag till konstnärlig utsmyckning (fristående skulpturer [...] i anslutning till uteplats). Byggnadsstyrelsen har efter samråd med brukaren KTH:s representanter från RÄ och referensgrupp för KTH-E (yttrande 89-02-01) samt representanter från byggnadsansvarig enhet KBS-Ö/BPE (Tage Kihlgren/Erik Eriksson) funnit att det från KBS-Ö/BP:s sida inte finns något att erinra emot att Ebba Ahlmarks ovannämnda konstverk utförs enligt förevisad modell och materialprov under förutsättning att följande villkor beaktas och av konstrådet förankras i kontraktet med konstnären ${ }^{56}$

Varpå följde noggranna specifikationer om tidsplan, kostnader, betalningsterminer, socklarnas utförande, ytskydd mot klotter m.m. Exempelvis: "Konstnären disponerar under tiden från 1990-08-15 till 1990-09-15 ett inhägnat område av 3 x 3 meter kring skulpturerna för att ostört kunna utföra uppsättningen av skulpturerna. Överenskommelse om tider och tillstånd för Ebba Ahlmark-Hughes 


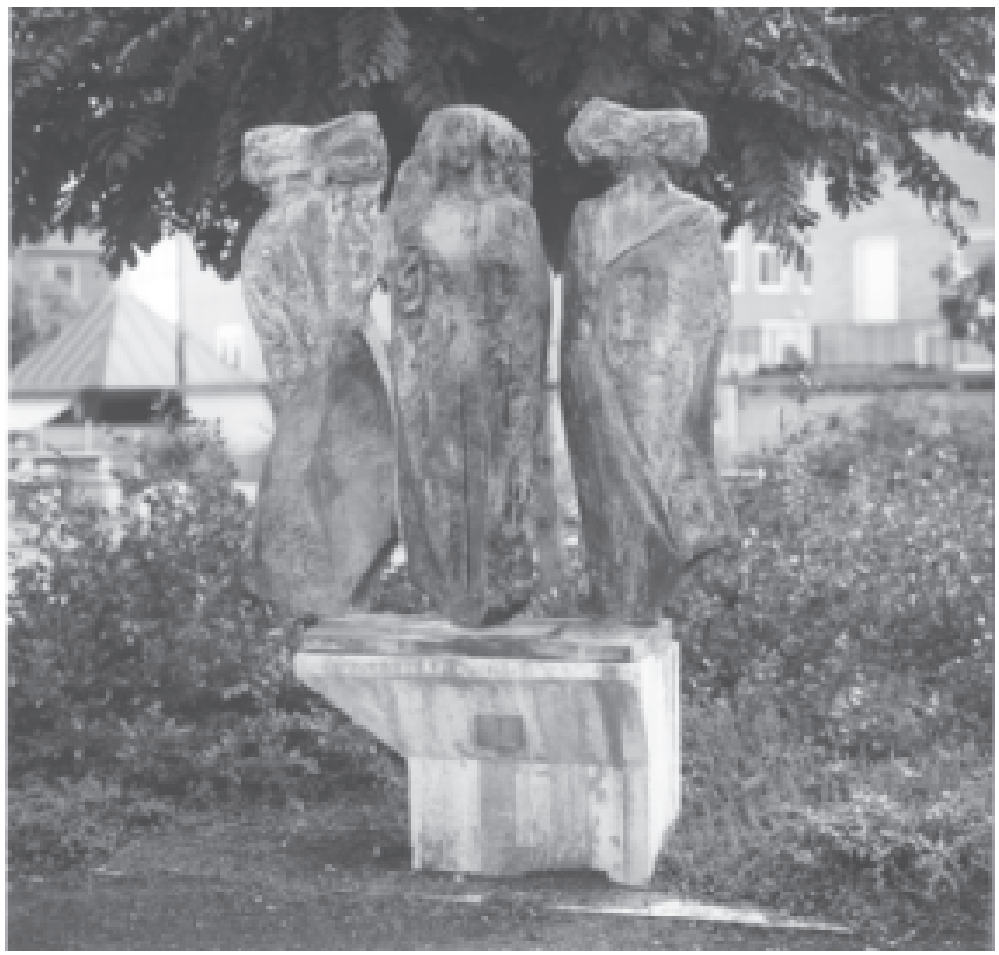

Fig.4. Skulpturgruppen "Framtiden, Nutiden, Förflutet" av Ebba Ablmark-Hughes 1990 vid den nya Elektroteknikbyggnaden på Kungl. Tekniska Högskolan. Notera att figurerna "Nutid" och "Förflutet" inte är sammangjutna. Foto: Tomas Asplund 1997.

att tillträda platsen skall träffas med byggansvarig KBS-Ö/BP-E Erik Eriksson". ${ }^{57}$ Styrkta av detta upprättade Statens konstråd ett kontrakt mellan sig och Ahlmark-Hughes. ${ }^{58}$ Det var ett standardformulär som i första hand behandlade Byggnadstyrelsens ansvar vad gällde gjutning av fundament etc., en tidsplan för konstnärens åtagande samt hur arvodet skulle utbetalas stegvis i takt med att arbetet utfördes och godkändes. I Statens konstråds förtryckta standardformulär fanns också sådana byråkratiska guldkorn som följande:

Om statistiska centralbyråns konsumentprisindex sti- git till 180,5 skall därefter kommande utbetalningar ändras i direkt proportion till indexhöjningen, räknad från dagen för skissförslagets godkännande enligt $\$ 1$ till respektive betalningstillfällen, dock längst till den dag då konstrådet slutligen godkänner arbetet. ${ }^{59}$

Mycket hade skett för att formalisera den offentliga utsmyckningen sedan Axel Törneman 1917 åtog sig ett liknande uppdrag i vad som då också var en nybyggnad för KTH:s Elektrotekniska sektion: Då fick han först 1000:$\mathrm{kr}$ i handen för skisserna och sedan 10.000:$\mathrm{kr}$ för att uppföra takmålningen. ${ }^{60}$

$\mathrm{KTH}:$ referensgrupp besökte Bergmans 
44 konstgjuteri, där skulpturgruppen skulle gjutas, och fick se skulpturerna i full storlek. ”De hade, naturligt nog, förändrats under uppförstoringen och [...] kvinnofigurerna hade utvecklats i expressivitet". ${ }^{61}$ Det nya E-huset invigdes våren $1990,{ }^{62}$ och då återstod bara två ting för Statens konstråd: Först en avsyningsrapport signerad av projektledaren, ${ }^{63}$ och därefter det formella överlämnandet av konstverket från Statens konstråd till Byggnadsförvaltningen i Stockholm:

Statens konstråd överlämnar härmed

EBBA AHLMARK HUGHES

'Framtid, nutid, förflutet', skulpturgrupp

Stockholm; KTH, sekt E, elektroteknik.

Konstverket har nu placerats i färdigt skick.

Konstverket har 1991-09-25 slutligt godkänts av statens konstråd från konstnärlig synpunkt. Skissförslag till utformning av nämnda verk har dessförinnan godkänts av såväl mottagare som byggande resp byggnadsförvaltande myndighet för genomförande och placering hos myndigheten.

Konstverket/konstverken har förvärvats för en bestämd placering och är infogade i en särskild miljö. En ändrad placering, eller andra väsentliga förändringar som rör konstverken, får därför göras endast i samråd med den myndighet som har tillsynen över konstverken och, i den mån det följer av lagen (1960:729) om upphovsrätt, med konstnären.

Tillsyningsmyndighet är: Statens Konstmuseer Box 16176

10324 Stockholm ... osv." ${ }^{64}$

Visst kan man dra på munnen åt detta, men då bör man å andra sidan betänka att lika hårda regler gällde inte för de byråkrater som byggde bort Törnemans takmålning på 1950-talet, eller för de tjänstemän som skyfflade statyn av Nils Ericson fram och tillbaka längs Vasagatan under sent 1900-tal (se not 34). Som idéhistoriker är man kanske tacksam för det, ty därmed kunde offentliga symboler försvinna i takt med att tidsandan förändras utan några fördröjningar av ett statligt regelverk; något som förenklar analysen.

I Statens konstråds årskatalog 1991 citeras Ebba Ahlmark-Hughes egen beskrivning av skulpturgruppen:

Den centrala gruppen består av tre kvinnofigurer. Den främsta, framtiden, ser framåt och har i sin rörelse och blick en antydan av galjonsfigur. Nutiden ses i enface. Det förflutna representeras av den tillbakablickande kvinnofiguren. ${ }^{65}$

Det intressanta med dessa tre figurer är deras inbördes samband. Figurerna "Framtid" och "Nutid" är nämligen förbundna med brons, sammangjutna, men mellan figurerna "Nutid" och "Förflutet" finns inget samband: Mellan dem är en springa luft genom vilken ljuset skiner. Fanns det en uttalad tanke i det faktum att två av kvinnofigurerna var sammanfogade men den tredje fristående? Nej, det ansåg inte konstnären:

Där har inte i någon väsentlig mening symbolik kommit att spela roll vid utformandet. Den visuella känslan har fått avgöra. Balans och förhållandet mellan positiva och negativa former samt en önskan att inte en likformning skulle förta rörelsen i skulpturen. ${ }^{66}$

Fast å andra sidan hade KTH:s referensgrupp haft tillfälle att vid flera möten med konstnären lämna sina synpunkter på konstverket. För konstnären hade kanske inte denna symbolik någon betydelse, men skulpturgruppen var ett förslag som tilltalade KTH:s referensgrupp. En tolkning av denna smala springa luft skulle kunna vara att skulpturgruppen uttrycker uppfattningen att det inte finns någon förbindelse mellan Förflutet - den för tekniksamhället irrelevanta historien - och den hektiska $\mathrm{Nu}$ tid som har knutit förbund med Framtiden. 
Det förvånar därför inte att KTH:s referensgrupp "var mycket förtjust i förslaget" ${ }^{67}$

De hundratals studenter och forskare som varje dag passerar skulpturen har säkert redan slutat att se den, den har smält in i den allmänna bakgrund som utgör vardagens miljö. Precis som jag själv slutade se vimpeln på flaggstången utanför mitt barndomshem. Ja, på samma sätt som teknologerna i hörsalen till Fackskolan för elektroteknik inte längre lyfte på huvudet på 1950-talet för att se på Törnemans takmålning - men ändå finns här en skillnad ty dess symboliska innehåll har ännu sin relevans. Skulpturen illustrerar nämligen tekniksamhällets förändrade syn på tidens problematik, på förhållandet mellan framtid, nutid och det förgångna: Hur detta tidens smala näs mellan nutid och förflutet har brutits i denna nutids strävan att knyta förbund med framtiden - och här är dessa ambitioner gjutna $\mathrm{i}$ brons.

\section{$* * *$}

Frågan om hur kollektiva symboler skapas och hur de tyst tillåts försvinna har här illustrerats med en rad exempel: Med artefakter som t.ex. flaggor och fanor, byggnader, en neonskylt utanför en biograf, ett elektronrör, en takmålning och en skulpturgrupp - men också med en individ som Nobelpristagaren Hannes Alfvén. Han - eller snarare den mediala bilden av honom - blev en symbol för samtidens förhoppningar om att vetenskaplig grundforskning skulle leda till teknisk utveckling och ekonomisk tillväxt och därmed stärka Sveriges ställning internationellt.

Uppsatsen har sökt visa hur relativt svårt det är för en historiker att rekonstruera de processer som skapar en symbol respektive får den att falla i glömska och försvinna. ${ }^{68}$ Det sistnämnda är särskilt viktigt, ty om vi kan be- stämma vilka värderingar en symbol stod för vid sin tillkomst så säger dess tysta försvinnande oss att samtiden inte längre delade dessa värderingar. Att studera hur symboler försvinner eller tynar bort blir därmed också ett sätt att studera värderingars förändringar. Historiska studier av dessa symbolers tillkomst och försvinnande kan ge en indikation om vilka föremål museerna bör bevara och hur dessa bör presenteras för att gestalta ännu en bild av det förflutna.

\section{Noter}

1. Svenska flaggans dag infördes 1916. Firandet ägde länge rum på Stadion, men flyttades 1963 till Skansen, se: Arne Biörnstad, "Den svenska flaggans dag", i: Leif Jonsson \& Eriq Norberg, eds., Från fälttåg till folkfest: Nordiska flaggor, fanor och symboler (Stockholm: Föreningen Norden/Lidköping: Läckö institutet, 1993), pp. 5972; Stig Herbst, Svenska flaggans dag 50 ar (Stockholm, 1965).

2. Cf. Matt K. Matsuda, The Memory of the Modern (Oxford: Oxford University Press, 1996), pp. 18-39 (Ch.1 "Monuments: Idols of the Emperor").

3. Det är alltså delvis en annan frågeställning än den Magnus Rodell behandlar i sin avhandling. Där studerar han tre exempel på tillkomsthistoria och ceremonier vid invigningen av statyer $\mathrm{i}$ Sverige under 1800-talet som ett led i konstruerandet av en nationell identitet, se: Magnus Rodell, Att gjuta en nation: Statyinvigningar och nationsformering i Sverige vid 1800-talets mitt, diss. (Stockholm: Natur och Kultur, 2001).

4. Ett resonemang kring den blivande bokens struktur har publicerats som: Svante Lindqvist, " $\mathrm{La}$ lagom longue durée: Tidsanda och struktur i en studie kring Hannes Alfvén”, i: Evert Baudou, ed., Forskarbiografin: Föredrag vid ett symposium $i$ 
Stockholm 12-13 maj 1997, KVHAA Konferenser 41 (Stockholm: Vitterhetsakademien, 1998), pp. 143-157.

5. Svante Lindqvist, "An Olympic Stadium of Technology: Deutsches Museum and Sweden's Tekniska Museet", History and Technology 10 (1993), pp. 37-54. (Även på franska som ”Des olympiades de la technologie: Le Deutsches Museum et le Tekniska Museet", i: Brigitte Schroeder-Gudehus, ed., La Société industrielle et ses musées: Demande sociale et choix politiques 1890-1990 (Paris: Édition des archives contemporaines, 1992), pp. 119-149.)

6. SvD 18 juni 1949; ibid. 10 februari 1950; DN3 juli 1954.

7. ST 4 februari 1960; DN28 juni 1961.

8. Svante Lindqvist, "Forskningens fasader: Wenner-Gren Center som symbol för svensk vetenskap”, Lychnos 1997, pp. 119-156. Cf. Jan Wallander, Wenner-Gren stiftelserna 1955-2000: Hur fäfänga visioner och världsförbättrarnit blev grunden till stora stiftelser (Stockholm: Atlantis, 2002). Engelsk utgåva: idem, The Wenner-Gren Foundations 1955-2000: How Vanity, Visions and OverAmbitious Plans to Improve the World Led to the Creation of Great Foundations (Stockholm: Atlantis, 2002).

9. Svante Lindqvist, "Harry Martinson och Biografen Elektron i Gnesta", Artes: Tidskrift för litteratur konst och musik 20 (1994), nr. 3, pp. 14-27. Ingår även på engelska i: idem, "Introductory Essay: Harry Martinson and the Periphery of the Atom", i: idem, ed., Center on the Periphery: Historical Aspects of 20th-Century Swedish Physics (Canton, Mass.: Science History Publications, 1993), pp. xi-lv.

10. Tekniken och morgondagens samhälle (Stockholm: Tidens Förlag, 1956), citat baksidestexten. Cf. Stefan Lindström, Hela nationens tacksamhet: Svensk forskningspolitik på atomenergiområdet 1945-1956, diss. (Stockholm: Stockholms uni- versitet, 1991), pp. 140-144.

11. Gunnar Hambræus, "Svensk teknisk forsknings dilemma", SvD 3 mars 1950.

12. Stefan Boman har skrivit en fascinerande bok om de svenska historiska museerna och nationalism (dock utan att nämna just Tekniska Museet), se: Stefan Bohman, Historia, museer och nationalism (Stockholm: Carlsson, 1997).

13. Nobelstiftelsens högtidsdag den 10 december 2001: Banketten Stadshuset, programblad 4 pp. (Stockholm: Nobelstiftelsen, 2001).

14. Svante Lindqvist, "Ideology and Institutional Structure: The Historical Origins of the Present Crisis in Swedish Engineering Schools", i: Giuliano Pancaldi, ed., "Universities and the Sciences: Historical and Contemporary Perspectives", special issue of the Bologna University journal Alma Mater Studiorum 1993, pp. 181-199. (Även i italiensk översättning: ibid., pp. 200215.); idem, "A Cost-Benefit Analysis of Science: The Dilemma of Engineering Schools in the 20th century", i: Ingmar Grenthe, ed., Science, Technology and Society: University Leadership Today and for the Twenty-First Century, Stockholm Papers in Library and Information Science (Stockholm: KTH, 1998), pp. 105-116; idem, "Teknologins institutioner som spegelbild av Sveriges industriella historia", Kungl. Vitterhets Historie och Antikvitetsakademiens årsbok 1994, pp. 122-135.

15. Svante Lindqvist, "Universiteten på marknaden", i: Gunnar Eriksson \& Karin Johannisson, eds., Den akademiska gemenskapen: Universitet och idé, ett symposium till Tore Frängsmyrs 60-årsdag, Inst. för idé- och lärdomshistoria, Uppsala universitet, Skrifter 21 (Uppsala, 1999), pp. 39-44.

16. Cf. Ulf Larsson, Brobyggaren: Otto Linton, byggnadskonsten och dess professioner i Norden under första delen av 1900-talet, Stockholm Papers in the History and Philosophy of Technology TRITA-HOT-2031 (Stockholm: Carlssons, 1997), 
pp. 9-12.

17. Svante Lindqvist, "Teknik, kultur och bildning: Den svenska ingenjörskårens förvandling", i: Lars Grahn et al., eds., Bok och bildning: Natur och Kultur 75 år (Stockholm: Natur och Kultur, 1997), pp. 129-153.

18. Hannes Alfvén, Sagan om den stora datamaskinen: En vision av Olof Johannesson (Stockholm: Pilgrim Press, 1987), pp. 155-158 ("Efterskrift: Operan. Den ofullbordade"). - Första upplagan publicerad under pseudonym som: Olof Johannesson, Sagan om den stora datamaskinen: En vision (Stockholm: Bonniers, 1966).

19. Svante Lindqvist, "Spatial Networks of Technological Change: Social Mobility between Industry and University", i: Janne Carlsson, ed., Knowledge as Substitute for Natural Resources: The Curt R. Nicolin Seminar at the Royal Institute of Technology (Stockholm: KTH, 1994), pp. 9-27.

20. Sven Widmalm har tillämpat en liknande metodik i sin studie av bilder i pressen av The Svedberg, se: Sven Widmalm, "Trollkarlen från Uppsala: Mediabilden av The Svedberg och vetenskapen under andra världskriget”, MS. augusti 2003, 27 pp., som kommer att publiceras i: Anders Ekström, ed., Den mediala vetenskapen (under utgivning).

21. Om Nobelprisens första hundra år liksom om Alfred Nobel har jag skrivit i tidens anda, men jag arbetar nu på en kritisk granskning av bilden av såväl prisen som dess upphovsman, se: Svante Lindqvist, "100 år med nobelprisen", Nationalencyklopedins årsbok 2001, vol. 26 (Malmö: Bra Böcker, 2002), pp. 150-152; idem, Alfred Nobel: Inventor, Entrepreneur and Industrialist (18331896), IVA Meddelande 335 (Stockholm: Ingenjörsvetenskapsakademien, 2001), 42 pp.

22. Svante Lindqvist, "Om konsten att ligga lågt, inte sticka upp och sitta ned i båten: Hannes Alfvéns utträde ur IVA och kvarblivande i KVA", i: Till en konstnärssjäl: En vänbok till Stig Ramel
(Stockholm: Atlantis, 2002), pp. 209-225. Cf.

Jonas Anselm, Mellan frälsning och domedag: Om kärnkraftens politiska idéhistoria i Sverige 19451999 (Stockholm/Stehag: Symposion, 2000), esp. 117-127.

23. Ragnar Widegren, Konsten på Kungl Tekniska Högskolan (Stockholm: Byggförlaget, 1992). Cf. Erik Lallerstedt, "Beskrivning över Kungl. Tekniska Högskolans nybyggnader", i: Historik och beskrivning rörande nybyggnaderna jämte avhandlingar och uppsatser av högskolans lärare, Skrifter utgivna med anledning av inflyttningen i de år 1917 färdiga byggnaderna (Stockholm: Kungl. Tekniska Högskolan, 1918).

24. Ragnar Widegren, Axel Törnemans takmålning på KTH àter i dagen efter fyra decennier (Stockholm: Kungl. Tekniska Högskolan, 1994). - Om Axel Törneman, se i första hand: Anita Theorell, Axel Törnemans Riksdagshusmålningar, diss. (Stockholm, 1973). Se också: Göran Söderlund, ed., Axel Törneman, Millesgårdens utställningskatalog nr 24 (Stockholm: Millesgården, 1990); Carlo Derkert \& Algot Törneman, eds., Axel Törneman och kvinnan, Moderna museets utställningskatalog nr 45 (Stockholm: Moderna Museet, 1965); Axel Törneman 1880-1925: Liljevalchs konsthall 15 september - 15 oktober 1967, Liljevalchs katalog nr 274 (Stockholm, 1967); Birgitta Rubin, "Axel Törneman: den första svenska modernisten", i: Carl-Henrik Reiher, ed., Sandhamnsledens öar, Skärgårdsstiftelsens årsbok 1995, vol. 23, pp. 155-158; Janna Törneman, "Skagnäs: Axel Törnemans sommarhem", Cuppsats vid Konstvetenskapliga institutionen, Stockholms universitet, 2002; Magnus Källström, "Nattcafé: Om Axel Törnemans tid i Paris 1902-1906", C-uppsats vid Konstvetenskapliga institutionen, Stockholms universitet, 1988.

25. Anita Theorells avhandling behandlar striderna kring Törnemans Riksdagshusmålningar, se: Theorell 1973. 
26. Citerat efter Widegren 1994, p. 29.

27. Ibid., p. 13.

28. Ibid., p. 7. - Att Axel Törneman kom från en verklig "ingenjörsfamilj" med starka kopplingar till KTH har inte tidigare uppmärksammats. Hans far Algot Törneman (1851-1942) hade studerat på Teknologiska Institutet (KTH:s föregångare) under åren 1868-1871. Han var först föreståndare för Gyttorps nitroglycerinfabrik 1872-1874, och han anlade sedan Persbergs gruve $\mathrm{AB}$ :s nitroglycerinfabrik 1874 som han förestod i hela femtio (!) år, till 1925. I Norge anlade han också en nitroglycerinfabrik 1876 och en salpeterfabrik 1879 samt var innehavare av Hasselgrens färgfabrik i Stockholm 1880-1887. Axel Törnemans yngre bror, Yngve Törneman (1887-1960) studerade på KTH 1908-1909 och blev 1919 överingenjör vid Surahammars bruk. Han gifte sig med dottern till överingenjör Teodor Rooth (1858-1926) (som också hade studerat vid Teknologiska Institutet, 1875-1878), och minst två av deras tre söner blev ingenjörer. Se: Govert Indebetou \& Erik Hylander, eds., Svenska Teknologföreningen 1861-1936: Biografier (Stockholm: Svenska Teknologföreningen, 1937) vol. 1, pp. 145-146 \& 222; vol. 2, pp. 846-847. - Att fadern var en mycket framgångsrik entreprenör kan förklara varför Axel Törneman hade råd att studera utomlands i flera år. Hans familjebakgrund antyder också att han hade en icke oansenlig teknisk-naturvetenskaplig bakgrund (om än informell) när han åtog sig uppdragen för Kungl. Tekniska Högskolan 1917.

29. Widegren 1994, pp. 8-11.

30. Ibid., pp. 14-15.

31. Ibid., p. 15.

32. Ibid., p. 16-17.

33 I Lexikon för konst 1960 stod det t.ex. i artikeln om Törneman att "I Tekniska högskolan i Stockholm utförde T. 1918 takmålningen De elektriska strömmarna (nu nedtagen)", se Lexikon för konst, vol. 3 (Stockholm: AB Nordiska Uppslagsböcker, 1960), p. 1617. - Ragnar Widegren skrev 1992 (då han trodde att målningen befann sig dolt av ett nytt innertak i fysikhörsalen, och ett år innan målningen återfanns) i sin bok om konsten på KTH att "Tyvärr har hörsalen av akustiska skäl numera försetts med ett innertak som helt skymmer målningen”. Denna uppgift dementerade han två år senare, och han medgav att när restaureringen av KTH:s huvudbyggnad började planeras 1993 "var man inte alls säker på att målningen verkligen fanns kvar". Se: Widegren 1992, p. 56; Widegren 1994, pp. 16-17 \& 19,

34. Ett exempel är statyn av järnvägsbyggaren friherre Nils Ericson, bror till den svensk-amerikanske uppfinnaren John Ericsson. Över honom restes en staty, utförd av bildhuggaren John Börjeson, utanför Centralstationen i Stockholm. Den invigdes den 8 september 1893, men lika känt är inte datum eller ens året när den togs bort. Någon gång på 1970-talet hade den nämligen blivit otidsenlig och flyttades till en undanskymd plats under Centralbron (på den ödsliga och folktomma cementplatta som går under det eufemistiska namnet "Stationsparken"). Men på 1990-talet hade tidsandan - precis som i fallet med den samtida återupptäckten av Törnemans målning åter svängt om, och sedan några år står Nils Ericsons staty åter utanför huvudingången till Centralstationen (vars stora huvudbyggnad, liksom Wenner-Gren Center, har förlorat sin ursprungliga roll och nu utbjuds som kontorslokaler). - Nämnas kan att bysten av brodern John Ericsson i Berzelii park - också utförd av John Börjeson och invigd 1901 - har överlevt alla dessa turer och fått stå kvar.

35. Bo Sundin, Mellan hat och kärlek: En berättelse om anden i naturen och upptäckten av elektromagnetismen (Stockholm: Riksutställningar, 1987).

36. Ibid., p. 34.

37. "Solen på plats i Törnemansalen", KTH-nytt 
1997, nr 2, p. 17.

38. Karin Johannisson, Den mörka kontinenten: Kvinnan, medicinen och fin-de-siècle (Stockholm: Norstedts, 1994), pp. 87-94.

39. Ibid., p. 87.

40. Ibid., p. 89. - Johannisson beskriver hur "temat kvinnohälsa behandlades i en yvigt växande populärvetenskaplig litteratur fr.o.m. sekelskiftet" (p. 89). Framtidens hopp och statens livskraft ansågs vila på ett friskt, starkt kvinnlig släkte och hälsosamma livsstilar och gymnastiska övningar sågs som nya kvinnliga dygder. Johannisson beskriver hur kvinnan blev huvudmålgrupp för det tidiga 1900-talets rashygien, hälsokampanjer och hygienistiska propaganda. I den medicinska litteraturen lanseras nya idealutseenden, och rasbiologerna gjorde sitt för att typologisera den perfekta kvinnokroppen. Kraftig och vitalvar nya kodord. "Skyddet av den kvinnliga organismen", skriver hon, "lanseras som en nationell överlevnadsstrategi. [...] [K]vinnans hälsa fick en ny dimension, fördes upp på ett samhälleligt plan och blev till en medborgerlig plikt i nationens, folkhälsans och framtidens namn" [...] Den sunda kvinnokroppen blev en del av det moderna projektet - en projicering av en rationaliserad, disciplinerad ordning" (pp. 90-92). Det var dessa föreställningar, skriver Johannisson, som låg bakom 1911 års betänkande om moderskapsförsäkring vilket 1912 års riksdag behandlade. Och hon beskriver hur en fransman på genomresa i Sverige på 1920-talet förundrades över den friska och spänstiga svenska kvinnan. ”Lång, smalhöftad, småbröstad utgjorde hennes själva kroppstyp en inkarnation av modernitet" (p. 92).

41. Theorell 1973, pp. 24-27; idem, ”'... En som haft linjen till fluga en längre tid...'”, i: Söderlund 1990, pp. IX-XIX, esp. XV-XVII.

42. Ulf Linde, Vägledning till Thielska Galleriet (Stockholm, 1992), p. 28.

43. Derkert \& Törneman 1965, pp. $1 \& 4$.
44. "Han" skriver jag, ty andelen kvinnliga teknologer på KTH var blygsam på 1950-talet. På Sektionen för elektroteknik var andelen bara några enstaka procent. Se: Anna Karlqvist, Från eftersatt till eftersökt: Om kvinnliga studeranden på Kungl Tekniska Högskolan, Stockholm Papers in History and Philosophy of Technology TRIAHOT-2034 (Stockholm: Kungl. Tekniska Högskolan, 1997), pp. 36-39.

45. ASEA anslog 10.000 kronor år 1917 till dess utförande, vilket ungefär svarade mot en årslön för en professor vid den tiden. År 1994 kostade det minst 1,5 miljoner kronor att flytta den, men ingen exakt siffra har angivits.

46. Statens konstråds årkatalog (22) 1991, p. 27. Cf. Widegren 1992, pp. $98 \& 100$.

47. Brev från avd. dir Elsa Österman, Byggnadskommitténs kansli, Kungl. Tekniska Högskolan, till författaren, daterat 8 september 1995, 2 pp. Referensgruppen bestod av prof. Lars-Henning Zetterberg, högskolelektor Eilert Berglind, docent Erling Dahlberg, professor Bengt Hidemark, avd. dir Elsa Österman samt arkitekten Heinz Hanus från Kungl. Byggnadsstyrelsen.

48. Brev från Ebba Ahlmark-Hughes till författaren daterat den 19 oktober 1995, 3 pp. - Arkitekterna var Bengt Hidemark och Thomas Kempe, av vilka Hidemark också ingick i KTH:s referensgrupp.

49. Brev från Österman op. cit.

50. Brev från Ahlmark-Hughes op. cit.

51, Brev från Österman op. cit.

52. Ibid.

53. Brev från Ahlmark-Hughes op. cit.

54. Ibid.

55. Statens konstråds arkiv, DD nr 32-250/87, Brev från avd. dir. Elsa Österman, Tekniska byrån, Rektorsämbetet, Kungliga Tekniska Högskolan, till Byggnadsstyrelsen Östra regionen, att: Heinz Hanus, daterat 1 februari 1989, 1 p.

56. Statens konstråds arkiv, DD nr 32-250/87, Brev 
från Heinz Hanus, Byggnadsstyrelsen Östra regionen, till Bertil Björkqvist/Curt Thorsjö, Statens Konstråd, daterat 17 mars 1989, 2 pp.

57. Ibid.

58. Statens konstråds arkiv, DD nr 32-250/87, Kontrakt mellan Statens konstråd och Ebba Ahlmark-Hughes, daterat 31 mars 1989, 2 pp.

59. Ibid.

60. Widegren 1994, pp. 7 \& 13. - Ebba AhlmarkHughes fick 30.000:- som skissarvode och 400.000:- för utförandet (enligt kontraktet och avsyningsrapporten, se nn. $58 \& 63$ ).

61. Brev från Österman $o p$. cit.

62, "Nya E-huset invigt”, KTH-nytt 1990, nr 8 (april), p. 14.

63. Statens konstråds arkiv, DD nr 32-250/87, Avsyningsrapport rörande "Framtid, nutid, förflutet" daterad 25 september 1991, 1 p.

64. Statens konstråds arkiv, DD nr 32-250/87, Brev från Statens konstråd till Byggnadsförvaltningen i Stockholm, daterat 14 oktober 1991, 1 p.

65. Op. cit. Originalet i: Statens Konstråds arkiv, DD nr 32-250/87, 25 november 1988, PM av Ebba Ahlmark-Hughes, "Motto: 'Framtid, Nutid, Förflutet"', 2 pp.

66. Brev från Ahlmark-Hughes op. cit.

67. Brev från Österman op. cit.

68. Avd. dir Elsa Österman i KTH:s referensgrupp skrev t.ex. (ibid.) att "Slumpen gjorde att jag kastade min pärm om den konstnärliga utsmyckningen vid Q-husen i somras i samband med den förestående ombyggnaden här i huset. Jag har alltså inget skrivet material kvar [...] Det är möjligt att Erling [Dahlberg] eller Bengt Hidemark kan ha kvar några papper från tiden. Heinz Hanus har gått i pension och övriga referensgruppsledamöter tror jag knappast sparat några papper".

\section{SUMMARY}

\section{The Archeology of Symbols}

Symbols are created, manifested and ultimately disappear. This essay discusses how symbols are created, but also how they are rejected, destroyed or just simply fade away. The artefacts we preserve in the belief that they were important symbols in their own time had perhaps already lost their symbolic importance. This interest in symbols is a common theme in a study of the Swedish Nobel Laureate Hannes Alfvén and in scientific research in post-WW2 Sweden on which I have been working for a long time. Some examples of symbols for various beliefs concerning science and technology are given in this essay, and two examples are discussed in more detail. The first is a large ceiling painting in one of the lecture halls of the engineering college in Stockholm, the Royal Institute of Technology. It was executed by Axel Törneman (1880-1925) in 1917. The painting "disappeared" in the late 1950s and was rediscovered in 1993. The second example is a sculpture by Ebba Ahlmark-Hughes, erected in 1990, also at the Royal Institute of Technology. The essay tries to demonstrate how relatively difficult it is for the historian to reconstruct the processes by which symbols are created or destroyed. This is nevertheless important, particularly the latter question.

If we can determine the values a symbol signified when it was created, then its silent disappearence will tell us that these values were no longer shared by its surrounding. To study the disappearnce of symbols may thus also be of relevance in recreating the past.

\section{Museichef, professor Svante Lindqvist \\ Nobelmuseet \\ Box 2245, 10316 Stockholm \\ Fax: +46853481820 \\ E-mail: svante.lindqvist@nobel.se}

